\title{
BIOCHEMICAL EVALUATION OF FOCAL NON-REPERFUSION CEREBRAL ISCHEMIA BY MIDDLE CEREBRAL ARTERY OCCLUSION IN RATS
}

\author{
Benedicto Oscar Colli', Daniela Pretti da Cunha Tirapelli', Carlos Gilberto Carlotti Jr', \\ Luiza da Silva Lopes², Luis Fernando Tirapelli
}

\begin{abstract}
Cerebral ischemia is an important event in clinical and surgical neurological practice since it is one of the diseases that most compromise the human species. In the present study 40 adult rats were submitted to periods of focal ischemia of 30,60 and 90 min without reperfusion and animals submitted to a sham procedure were used as controls. We analyzed the levels of ATP, malondialdehyde and caspase3. No significant differences in the biochemical measurements were observed between the right and left brain hemispheres of the same animal in each experimental group. Reduced ATP levels were observed after the three periods of ischemia compared to the sham group. No significant increase in malondialdehyde or caspase-3 levels was observed. Despite significant changes in ATP levels, the results indicated cell viability in the ischemic region as shown by the low rates of lipid peroxidation and apoptosis, findings probably related to the lack of reperfusion.
\end{abstract}

KEY WORDS: cerebral ischemia, ATP, malondialdehyde, apoptosis.

\begin{abstract}
Avaliação bioquímica da isquemia cerebral focal, não associada à reperfusão, por oclusão da artéria cerebral média em ratos

Resumo - Isquemia cerebral é um acontecimento importante na prática neurológica clínica e cirúrgica, uma vez que é uma das doenças que mais comprometem a espécie humana. No presente estudo 40 ratos adultos foram submetidos a períodos de isquemia focal de 30,60 e 90 min e como controle foram utilizados animais do grupo sham. Foram analisados os niveis de ATP, malondialdeído e caspase-3. Nenhuma diferença significativa nas dosagens bioquímicas foram observadas entre os hemisférios cerebrais direito e esquerdo do mesmo animal em cada grupo experimental. Foi observada redução nos niveis de ATP após os três períodos de isquemia, em comparação com o grupo sham. Nenhum aumento significativo dos níveis de malondialdeído ou caspase-3 foi observado. Apesar das alterações significativas nos niveis ATP, os resultados indicaram viabilidade celular na região isquêmica como demonstrado pela baixa taxa de peroxidação lipídica e apoptose, achados que provavelmente estão relacionados com a falta de reperfusão.
\end{abstract}

PALAVRAS-CHAVE: isquemia cerebral, ATP, malondialdeído, apoptose.

Cerebral ischemia is an important event in clinical and surgical neurological practice since it is one of the diseases that most compromise the human species. In neurosurgical practice, arterial vasospasm after subarachnoid hemorrhage and arterial clamping represent two frequently occurring situations whose study is justified'. The lack of energy substrates and of oxygen due to the reduced blood flow triggers a series of successive events that compromise cell integrity, possibly leading to necrosis in the central area and to apoptosis, more frequently occurring in the area of penumbra surrounding the central area, or to both events $\mathrm{s}^{2,3}$. The pathophysiology of cell injury and death is poorly understood and therefore the therapeutic procedures commonly employed in ischemic events are essentially based on life support and on the treatment of the consequences of the injury, usually without intervening in the peri-ischemic phenomena which in most cases are the true cause of injury ${ }^{4}$.

The effects of cerebral ischemia can be evaluated by various methods ranging from clinical observation to sophis-

Faculty of Medicine of Ribeirão Preto, University of São Paulo, Ribeirão Preto SP, Brazil (FMRP/USP): 'Discipline of Neurosurgery, Department of Surgery and Anatomy; ${ }^{2}$ Discipline of Anatomy, Department of Anatomy and Surgery. Publication supported by CNPq.

Received 18 April 2008. Accepted 5 July 2008.

Dra. Daniela Pretti da Cunha Tirapelli - FMRP/USP - Avenida Bandeirantes 3900 - 14049-900 Ribeirão Preto SP - Brasil. E-mail: daniela@rca.fmrp.usp.br 
ticated biochemical methods that provide data about cell metabolism and permit the quantization of normal metabolic reactions in tissues, such as the activity of different enzymes $^{5-7}$, the determination and the study of the kinetics of neurotransmitter release from tissue $^{8}$, the determination of lipid peroxidation by the measurement of malondialdehyde (MDA), the dosage of intracellular ATP' ${ }^{9}$, and endothelial and mitochondrial function ${ }^{10}$. Our group has conducted several studies to evaluate the effects of cerebral ischemia using biochemical methods and the determination of mitochondrial function and of neurotransmitter release ${ }^{11-15}$.

The objective of the present study was to determine the energy metabolism patterns in the early phase of ischemia, aiming to avoid possible influence of reperfusion using ATP dosage, the patterns of oxidative stress based on lipid peroxidation with MDA measurement, and the patterns of apoptosis by caspase- 3 measurement.

\section{METHOD}

The experiment was carried out according to the Ethical Principles for Animal Experimentation adopted by COBEA (Brazilian College of Animal Experimentation).

Forty male Wistar rats weighing 250 to $350 \mathrm{~g}$ were divided into four experimental groups of 10 animals each. The animals of groups 1, 2 and 3 were submitted to 30,60 and 90 min of ischemia, respectively, by occlusion of the left middle cerebral artery (MCA) with intraluminal mononylon 4.0 suture introduced through the internal cervical carotid artery form an initial access though the artery ${ }^{16}$. The animals were anesthetized with halothane inhalation, submitted to orotracheal intubation and ventilated with a respirator, with monitoring of physiological pa- rameters. After ischemia the animals were killed and samples of the left (ischemic) and right (non-ischemic) brain hemisphere were collected for biochemical determinations and stored in liquid nitrogen at $-196^{\circ} \mathrm{C}$. Samples from the animals of group 4 (sham), considered to be the control of the surgical procedure, were similarly collected and stored.

\section{Biochemical evaluation}

Homogenates were obtained from the samples stored in liquid nitrogen using Tris- $\mathrm{HCl} 10 \mathrm{mM}$ Ph 7.4 and centrifuged $3000 \mathrm{~g}$ for 10 minutes at $4{ }^{\circ} \mathrm{C}$ (in Eppendorf 5417R centrifuge, Hamburg, Schleswig-Holstein, Germany). $150 \mathrm{mM} \mathrm{KCl}$ in $10 \mathrm{mM}$ Tris- $\mathrm{HCl}$ buffer, pH 7.4, and immediately used for all biochemical determinations. Protein dosage was performed in the supernatant using the method of biuret ${ }^{17}$, modified by addition of collate $1 \%^{18}$ and the aliquots of homogenate were stored at -70 . for all biochemical dosages.

\section{Determination of ATP}

Aliquots of the homogenate $(2 \mathrm{mg})$ were treated with perchloric acid $1 \mathrm{~N}$, neutralized with $\mathrm{KOH} 2 \mathrm{M}$, centrifuged and analyzed using the commercial Kit Adenosine 5'-Triphosphate (ATP) Bioluminescent Assay Kit (Sigma, Saint Louis, Missouri, USA). ATP levels are reported as $\mu \mathrm{M} \times 10^{-10} / \mathrm{mg}$ of protein.

\section{Determination of lipid peroxidation}

Peroxidation was determined spectrophotometrically using a commercial kit (Lipid Peroxidation Assay Kit, Cat. n? 437634, Calbiochem, San Diego, California, USA) for the detection of MDA together with 4-hydroxy-2(E)-nonenal (4-HNE). MDA levels are reported as $\mu \mathrm{M}$.

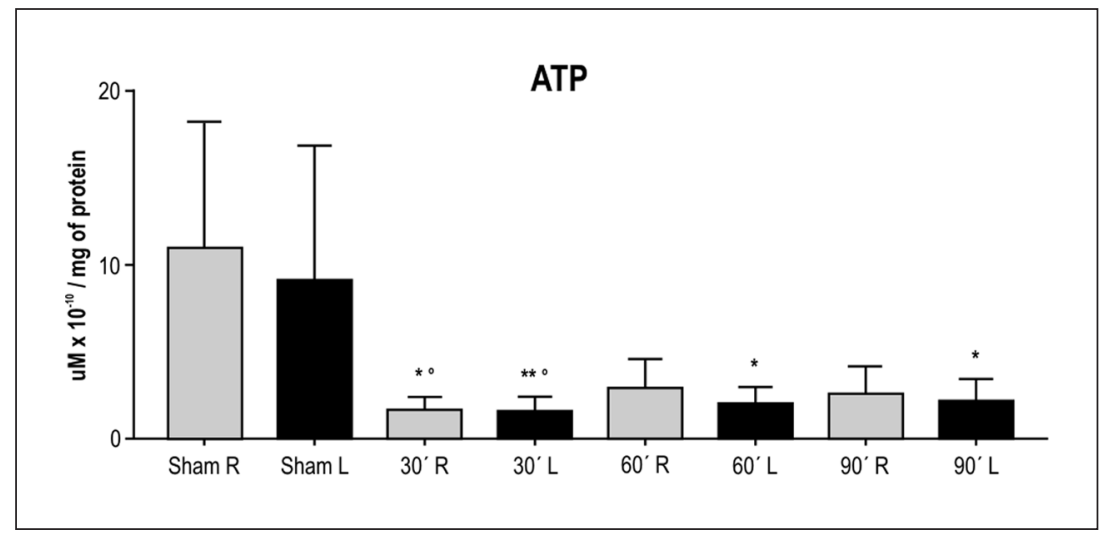

Fig 1. ATP levels in samples from the right $(R)$ and left $(L)$ brain hemispheres of sham animals and animals submitted to ischemia for 30,60 and $90 \mathrm{~min}$. Data are reported as means $\pm S D$. There was a significant difference between the samples from the right hemisphere $(p<0.0001$, one-way ANOVA), The Bonferroni multiple comparisons post-test showed a significant difference between sham $\times 30 \mathrm{~min}(p<0.001)$, sham $\times 60 \mathrm{~min}(p<0.001)$ and sham $\times 90 \mathrm{~min}$ $(p<0.001)$. There was a statistically significant difference between the samples from the left hemispheres ( $p<0.0003$, one-way ANOVA). The Bonferroni multiple comparisons post-test showed a significant difference between sham $\times 30 \mathrm{~min}(p<0.001)$, sham $\times 60 \mathrm{~min}(p<0.01)$ and sham $\times 90 \mathrm{~min}(p<0.01)$. 
Determination of caspase- 3 activity

Caspase-3 activity in the homogenate was determined using commercial kits (Caspase 3 Assay Kit, Colorimetric, Sigma, Saint Louis, Missouri, USA), Caspase-3 levels are reported as $\mu \mathrm{mol}$ pNA $\times 10^{-2} / \mathrm{min} / \mathrm{mL}$.

\section{Statistical analysis}

The results obtained for ATP, MDA and caspase-3, were compared between samples from the two hemispheres of the same animal using the nonparametric Wilcoxon test for paired samples, with the level of significance set at $p<0.05$. Comparisons between groups were made using one-way ANOVA nonparametric test followed by the Bonferroni post-test for multiple comparisons using the GraphPad PRISM software, version 2.0 (GraphPad Software Inc., San Diego, CA, USA).

\section{RESULTS}

\section{Determinaton of ATP}

The ATP levels (mean \pm SD) determined in samples of the right and left brain hemispheres of the animals in the four groups are presented in Figure 1. Application of the Wilcoxon test for paired samples revealed no significant differences in ATP concentrations between the left (ischemic) and right (non-ischemic) brain hemisphere of animals from the sham group ( $p=0.1602)$ or from the groups submitted to $30 \mathrm{~min}(p=1.000), 60 \mathrm{~min}(p=0.1309)$ and 90 min of ischemia ( $p=0.5566)$.

Despite a great dispersion in the results, there was a significant difference between the samples from the right $(p<0.0001$, one-way ANOVA) and left hemispheres of the experimental groups $(p<0.0003$, one-way ANOVA). The Bonferroni post-test for multiple comparisons showed a significant difference for the groups sham $\times 30 \mathrm{~min}$ $(p<0.001)$, sham $\times 60$ min $(p<0.001)$ and sham $\times 90$ min of ischemia $(p<0.001)$ in the right hemispheres and for the groups sham $\times 30$ min $(p<0.001)$, sham $\times 60$ min $(p<0.01)$ and sham $\times 90 \mathrm{~min}(p<0.01)$ in the left hemispheres.

\section{Determination of MDA}

Figure 2 presents the MDA levels (mean \pm SD) determined in samples of the right and left brain hemispheres of the animals in the four groups studied.

The Wilcoxon test for paired samples revealed no significant difference between the levels of MDA in the samples of the left (ischemic) and right (non-ischemic) brain hemispheres of the sham group $(p=0.6953)$ or of the animals submitted to $30(p=1.000), 60(p=0.0840)$ and $90 \mathrm{~min}$ of ischemia ( $p=0.9219)$.

There was no statistically significant difference between the samples obtained from the right brain hemispheres of the animals ( $p=0.3728$, one-way ANOVA), but there was a significant difference between the left brain hemispheres ( $p<0.0404$, one-way ANOVA). The multiple comparisons Bonferroni post-test showed a difference between the groups $60 \times 90$ min of ischemia $(p<0.05)$ in the samples from the left brain hemispheres.

\section{Determination of caspase-3}

The caspase-3 levels (mean \pm SD) determined in samples from the right and left brain hemispheres of the animals in the four groups are presented in Figure 3. The Wilcoxon test for paired samples showed no significant differences in caspase-3 levels in samples from the left (ischemic) and right (non-ischemic) brain hemispheres of the sham group ( $p=0.6250)$, or of the groups submitted to 30 $(p=0.2324), 60(p=0.9219)$ or $90(p=0.6953)$ min of ischemia.

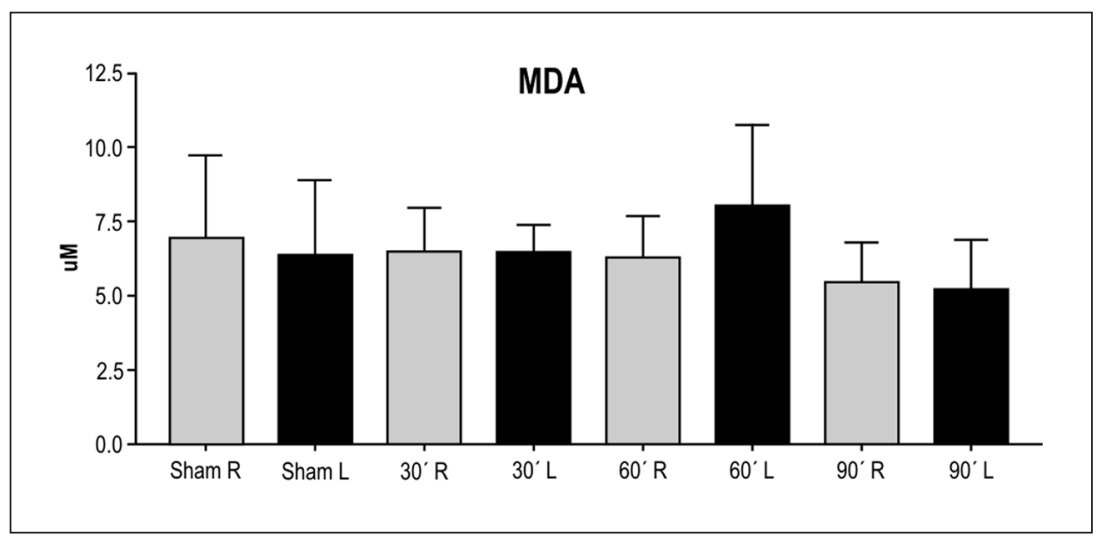

Fig 2. Malondialdehyde (MDA) levels in samples from the right $(R)$ and left $(L)$ brain hemisphere of sham animals and animals submitted to ischemia for 30,60 and $90 \mathrm{~min}$. Data are reported as means $\pm S D$. There was no significant difference between groups in the right hemispheres ( $p=0.0638$, one-way ANOVA) but there was a significant difference between groups in the left hemisphere ( $p=0.4694$, one-way ANOVA) and the multiple comparisons Bonferroni post-test showed a significant difference between the groups submitted to 60 and 90 min of ischemia $(p<0.05)$. 


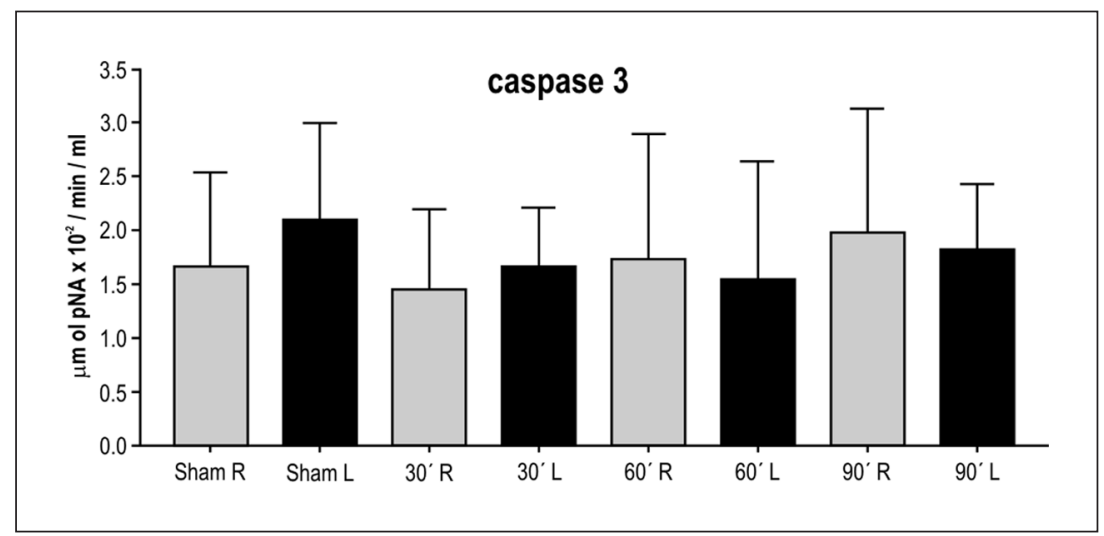

Fig 3. Caspase-3 levels in samples from the right and left brain hemispheres of sham animals and of animals submitted to 30,60 and 90 min of ischemia. There was no statistically significant difference between samples from the right $(p=0.6739)$ and left $(p=0.4694)$ hemispheres of the animals of all four experimental groups.

There was no significant difference between the samples from the right $(p=0.6739)$ and left $(p=0.4694)$ brain hemispheres of the animals in the four experimental groups.

\section{DISCUSSION}

ATP is a critical source of energy for the maintenance of the $\mathrm{Na}^{+} \mathrm{K}^{+}$ATPase ion pump, which regulates the ion concentration gradient for the generation of action potentials by the neurons, and its reduction has been suggested to be a critical factor in the determination of cell death ${ }^{19}$.

Energy-rich components such as ATP are necessary to maintain cell structure and functions such as active transport, protein synthesis and phosphorylation, synaptic transmission and the $\mathrm{Na}^{+} \mathrm{K}^{+}$ATPase ion pump which regulates the ion concentration gradient necessary for the generation of action potentials by the neurons ${ }^{19,20}$.

Energy status and metabolic changes can be demonstrated and evaluated earlier in temporary ischemia of short duration. As demonstrated in the literature, temporary ischemias ( 5 to $30 \mathrm{~min}$ ) impair the energy status of the cell, with partial or total recovery after reperfusion. Morphologic and functional changes are observed in a more delayed manner ${ }^{5,11,14,21,22}$.

Lee et al..$^{23}$ detected a small but significant reduction in the concentrations of ATP, ADP and phosphocreatine in the rat striate after $3 \mathrm{~h}$ of ischemia followed by $1 \mathrm{~h}$ of reperfusion, strongly indicating the presence of cell viability in this region. Hermann et al..$^{24}$ observed that intermittent unilateral occlusion of the MCA resulted in a delayed evolution of the focal infarct in the cerebral cortex, in the caudate nuclei, and in the putamen. This process, defined as a phenomenon of maturation of the ischemic lesion, is characterized by initial recovery of ATP metabolism in the brain, followed by slow and gradual failure secondary to the energy status. Zhan and Yang ${ }^{25}$ observed a significant decrease $(49 \%)$ in $\mathrm{Na}^{+} \mathrm{K}^{+}$ATPase activity in the brain of rats submitted to $2 \mathrm{~h}$ of ischemia and $22 \mathrm{~h}$ of reperfusion compared to the sham group, demonstrating secondary failure of the energy status of this organ, as reported by Hermann et al. ${ }^{24}$.

In the present study, in which we used focal ischemia without reperfusion, we observed a significant reduction in ATP in the animals of the ischemic groups compared to the sham group. However, this reduction occurred both in the ischemic and non-ischemic hemispheres, i.e., unilateral ischemia also caused a reduction of ATP production in both hemispheres. This was probably a global response to ischemic stress, as suggested by Harrison et al. ${ }^{26}$, regarding to the transient decrease in the caspase- 8 levels in both cerebral hemispheres of rats after $3 \mathrm{~h}$ of focal ischemia by occlusion of the left MCA.

Brain ischemia followed by reperfusion triggers a cascade of molecular events, among them lipid peroxida$\operatorname{tion}^{27}$. To assess the level of oxidative stress, Onem et al. ${ }^{28}$ estimated the levels of MDA, one of the most sensitive indicators of lipid peroxidation, and observed an increase in its levels after $15 \mathrm{~min}$ of ischemia followed by $15 \mathrm{~min}$ of reperfusion. Damage to membrane permeability due to lipid peroxidation can cause a reduction of the enzymatic activity of $\mathrm{Na}^{+} \mathrm{K}^{+}$ATPase in the membrane, of the release of lysosomal proteolytic enzymes and of the mitochondrial matrix in the cytoplasm, initiating intracellular proteolysis and cell destruction. Bas et al. ${ }^{29}$ observed that induction of ischemia for $45 \mathrm{~min}$ by occlusion of both carotid arteries followed by $30 \mathrm{~min}$ of reperfusion caused an accumulation of oxidation products, among them MDA and nitric oxide (NO), as well as induction of apoptosis in the hippocampal formation of rats. 
Some studies ${ }^{28,29}$ have demonstrated significant increases in MDA levels in experiments with ischemia followed by different periods of reperfusion, with lipid peroxidation being highly influenced during the period of reperfusion ${ }^{28}$. Serteser et al. ${ }^{30}$, in a study on rats submitted to $60 \mathrm{~min}$ of ischemia by MCA occlusion, observed changes in lipid peroxidation, with significantly higher MDA values in the ipsilateral cortex compared to the contralateral one. The present results show that there was no significant increase in MDA levels in ischemic animals compared to sham animals, a fact possibly explained by the absence of reperfusion, nor any difference between the ischemic and non-ischemic hemispheres.

Neurons are among the cells most vulnerable to an ischemic event. While complex processes including both necrosis and apoptosis seem to be involved in neuronal cell death, the mitochondria are known to be involved in both necrotic and apoptotic pathways by releasing mitochondrial proteins such as cytochrome $c$ and anti-apoptotic proteins ${ }^{31}$.

Apoptosis, which is controlled by cysteine-proteases, particularly caspases, is mediated by the mitochondrial release of apoptotic proteins, especially cytochrome c. The latter binds to the cytosolic protein Apaf-1 in the presence of ATP and facilitates the activation of caspase9, which in turn activates caspase- $3^{32}$. Several studies have indicated that cerebral ischemia and reperfusion can induce apoptosis in brain tissue ${ }^{31,33}$. Hermann et al. ${ }^{34}$, in a study of brain injury in mice after $30 \mathrm{~min}$ of focal ischemia followed by reperfusion, demonstrated that protein synthesis in the cerebral cortex was partially recovered after 24 and $72 \mathrm{~h}$ of reperfusion, but remained suppressed in the caudate nucleus and in the putamen. The mRNA levels for caspase- 3 in the caudate nucleus and in the putamen increased after $24 \mathrm{~h}$ of reperfusion and remained unchanged for 3 days, when the rate of protein synthesis was still decreased. However, the mRNA level for caspase3 did not increase in the cerebral cortex in which protein synthesis was recovered, demonstrating that the recovery of protein synthesis may be a factor that influences tissue survival after transitory focal ischemia.

After MCA occlusion for $1 \mathrm{~h}$ followed by reperfusion for 3 and $24 \mathrm{~h}$, Li et al. ${ }^{35}$ observed by immunohistochemistry an increase in the expression of caspase- 3 in the ischemic cortex of rats at 3 and $24 \mathrm{~h}$ of reperfusion, which was not observed immediately after the period of ischemia. In the present study, apoptosis assessed by the determination of caspase-3 in ischemic animals not submitted to reperfusion did not show a significant difference as reported by Li et al. ${ }^{35}$. These changes observed only after reperfusion indicate that "reperfusion injuries", which lead to a cascade of molecular events, seem to be of great importance for the expression of this apoptotic enzyme and for the consequent worsening of previous tissue changes.

The present study, in which focal ischemia was induced without reperfusion, demonstrated no significant differences in ATP, MDA or caspase-3 levels between the right and left brain hemispheres of each animal in each experimental group. Despite significant changes in ATP levels, the results indicated cell viability in the ischemic cortical region after $90 \mathrm{~min}$ based on the low rates of lipid peroxidation (absence of an increase in MDA) and on the apoptosis process (lack of increase in caspase-3 levels), suggesting that they seems to depend on the reperfusion injury and not only on the ischemic process.

\section{REFERENCES}

1. Selman WR, Lust WD, Pundiks S. Metabolic failure leads to the deterioration of the border zone in reversible focal ischaemia. Abstr Soc Neurosci 1992;18:1579-1587.

2. Tymianski M, Tator $\mathrm{CH}$. Normal and abnormal calcium homeostasis in neuron: a basis for the pathophysiology of tramatic and ischemic central nervous system injury. Neurosurgery 1996;38:1176-1194.

3. Pulsinelli, W. Pathophysioloy of the ischemic stroke. Lancet 1992;339:5336-5343.

4. Ginsberg MD. Local brain blood flow-metabolism interrelationships in an experimental model of diffuse cerebral isquemia. In: Meyer JS, Lechner H, Reivich M Ott EO (eds). Cerebral vascular disease. 3. Proceedings of the tenth international Salzburg conference. Amsterdam: Excerpta Med 1981;195-200.

5. Folbergrová J, Kiyota Y, Pahlmark K., Memezawa H, Smith Ml, Siesjö BK. Does ischemia with reperfusion lead to oxidative damage to proteins in the brain? J Cereb Blood Flow Metab 1993;13:145-152.

6. Matsuo Y, Onodera H, Shiga Y, et al. Correlation between myeloperoxidade-quantified neutrophil accumulation and ischemic brain injury in the rat. Stroke 1994;25:1469-1475.

7. Matsuo Y, Kihara T, Ikeda M, Ninomiya M, Onodera H. Kogure, K. Role of neutrophils in radical production during ischemia and reperfusion of the rat brain: effect of neutrophil depletion on extracellular ascorbyl radical formation. J Cereb Blood Flow Metab 1995;15:941-947.

8. Malinski T, Bailey F, Zhang G, Chopp M. Nitric oxide measured by a porphyrinic microsensor in rat brain after transient middle cerebral artery occlusion. J Cereb Blood Flow Metab 1993;13:355-358.

9. Nakagawa Y, Tayama K. Mechanism of mitochondrial dysfunction and cytotoxicity induced by tropolones in isolated rat hepatocytes. Chem Biol Interact 1998;116:45-60.

10. Piantadosi CA, Zhang J. Mitochondrial generation of reactive oxygen species after brain ischemia in the rat. Stroke 1996;27:327-331.

11. Carlotti CG Jr, Colli BO, Kazuo JY. Avaliação da isquemia cerebral pela respiração mitocondrial. Modelo experimental. Arq Neuropsiquiatr 2001;59:365-372.

12. Dias LAA, Colli BO, Coutinho J Neto, Lachat JJ. Avaliação da isquemia cerebral focal induzida pela oclusão da artéria cerebral média e a ação neuroprotetora do cetoprofeno em ratos. Arq Neuropsiquiatr 2000;5: 1047-1054.

13. Câmara RLB, Roselino JES, Colli BO. Swelling mitocondrial em amostras teciduais de gatos submetidos à oclusão da ACM. Acta Cir Bras 2001;16(Supl 1):S27-S31.

14. Duarte SG, Campos AD, Colli BO. Functional evaluation of temporary focal cerebral ischemia: experimental model. Arq Neuropsiquiat 2003;61:751-756

15. Nakano H, Colli BO, Roselino JES. Análise da respiração mitocondrial em tecido cerebral de gato após isquemia e reperfusão. Acta Cir Bras 2002;17(Supl 3):S34-S40.

16. Koiosumi J, Yoshida Y, Nakazawa T, Oneda G. Experimental studies of ischemic brain edema. 1. A new experimental model of cerebral embolism in rats in which recirculation can be introduced in the ischemic area. Jpn J Stroke 1986;8:1-8. 
17. Gornall AG, Paller MS. Determination of serum proteins by means of the biuret reaction. J Biol Chem 1949;177:751-757.

18. Kapla RS, Peder PL. Characterization of phosphate efflux pathways in rat liver mitocondrial. Biochem J 1983;212:279-288.

19. Erecinska M, Silver IA. ATP and brain function. J Cereb Blood Flow Metab 1989;9:2-19.

20. Mrsic-Pelcic J, Zupan G, Maysinger D, Pelcic G, Vitezic D, Simonic A. Prog Neuropsychopharmacol Biol Psychiatry 2002;26:1319-1326.

21. Lipton P. Ischemic cell death in brain neurons. Physiol Rev 1999;79: 1432-1516.

22. Smith WS. Pathophysiology of focal cerebral ischemia: a therapeutic perspective. J Vasc Interv Radiol 2004;15:3-12.

23. Lee DR, Helps SC, Gibbins IL, Nilsson M, Sims NR. Losses of NG2 and NeuN immunoreactivity but not astrocytic markers during early reperfusion following severe focal cerebral ischemia. Brain Res 2003;989: 221-230.

24. Hermann DM, Kuroiwa T, Hata R, Gillardon F, Ito U, Mies G. Expression of redox factor-1, p53-activated gene 608 and caspase 3 messenger RNAs following repeated unilateral common carotid artery occlusion in gerbis: relationship to delayed cell injury and secondary failure of energy state. Neuroscience 2001;102:779-787.

25. Zhan C, Yang J. Protective effects of isoliquiritigenin in transient middle cerebral artery occlusion-induced focal ischemia in rats. Pharmacol Res 2006;53:303-309.

26. Harrison DC, Davis RP, Bond BC, et al. Caspase mRNA expression in a rat model of focal cerebral ischemia. Brain Res Mol Brain Res 2001;89:133-146.
27. Schaller B, Graf R. Cerebral ischemia and reperfusion: the pathophysiologic concept as a basis for clinical therapy. J Cereb Blood Flow Metab 2004;24:351-371.

28. Onem G, Aral E, Enli Y, et al. Neuprotective effects of L-carnitine and vitamin $\mathrm{E}$ alone or in combination against ischemia-reperfusion injury in rats. J Surg Res 2006;131:124-130.

29. Bas O, Songur A, Sahin O, et al. The protective effect of fish n-3 fatty acids on cerebral ischemia in rat hippocampus. Neurochem Int 2007; 50:548-554.

30. Serteser M, Ozben T, Gumuslu S, Balkan S, Balkan E. Lipid peroxidation in rat brain during focal cerebral ischemia: prevention of malondialdehyde and lipid conjugated diene production by a novel antiepileptic, lamotrigine. Neurotoxicology 2002;23:111-119.

31. Sugawara T, Fujimura M, Noshita N, et al. Neuronal death/survival signaling pathways in cerebral ischemia. Neuro Rx 2004;1:17-25.

32. Namura S, Zhu J, Fink K, et al. Activation and cleavage of caspase-3 in apoptosis induced by experimental cerebral ischemia. J Neurosci 1998; 18:3659-3668

33. Zhang F, Yin W, Chen J. Apoptosis in cerebral ischemia: executional and regulatory signaling mechanisms. Neurol Res 2004;26:835-845.

34. Hermann DM, Kilic E, Hata R, Hossmann KA, Mies G. Relationship between metabolic dysfunctions, gene responses and delayed cell death after mild focal cerebral ischemia in mice. Neuroscience 2001;104:947-955.

35. Li JY, Furuichi Y, Matsuoka N, Mutoh S, Yanagihara T. Tacrolimus (FK506) attenuates biphasic cytochrome c release and bad phosphorylation following transient cerebral ischemia in mice. Neuroscience 2006;142:789-797. 